\title{
DETERMINATION OF THE VALUES OF MICROSTRUCTURAL AND MECHANICAL PARAMETERS OF A PEARLITIC 0.7\%C-0.60/0.70\%Mn STEEL WIRE ROD ENABLING TO ACHIEVE HIGH ABILITY TO DRAWING WITH THE USE OF LARGE CROSS SECTION REDUCTION
}

\author{
OKREŚLENIE WARTOŚCI PARAMETRÓW MIKROSTRUKTURALNYCH \\ I MECHANICZNYCH WALCÓWKI ZE STALI PERLITYCZNEJ \\ $0,7 \% \mathrm{C}-0,60 / 0,70 \% \mathrm{Mn}$ WARUNKUJĄCYCH WYSOKĄ PODATNOŚĆ \\ DO CIĄGNIENIA Z DUŻYM ODKSZTAECENIEM
}

The paper contains the results of microstructure investigation and measurement of mechanical properties of five batches of $5.5 \mathrm{~mm}$ diameter wire rod made of $0.7 \% \mathrm{C}-0.60 / 0.70 \% \mathrm{Mn}$ (C70D2/C72D2) carbon-manganese pearlitic steel, manufactured by five producers. The paper presents the analysis aimed at determining the values of parameters characterising the microstructure and mechanical properties of the wire rod allowing drawing with total a cross section reduction above 90\%. The required values of wire rod microstructural parameters were determined on the assumption that they are achievable in existing contemporary production lines for wire rod rolling and controlled cooling after rolling. Physical drawing simulations, a wide range of quantitative microstructure tests using light microscopy and scanning electron microscopy, and measurement of mechanical properties were performed. Drawability verification trials with large cross section reduction were performed in an industrial wire drawing plant.

Keywords: pearlitic wire rod, microstructure, mechanical properties, intense deformation drawing
Artykut zawiera wyniki badań mikrostruktury i pomiarów właściwości mechanicznych pięciu partii walcówki ze stali perlitycznej weeglowo-manganowej 0,7\%C-0,60/0,70\%Mn (C70D2/C72D2) o średnicy 5,5 $\mathrm{mm}$, wytworzonych przez pieciu producentów. Przedstawiono analize majaca na celu ustalenie wartości parametrów charakteryzujących mikrostrukture $i$ wtaściwości mechaniczne walcówki, umożliwiajace zastosowanie w procesie ciagnienia sumarycznego odksztatcenia powyżej 90\%. Wymagane wartości parametrów mikrostrukturalnych walcówki ustalono dla warunków możliwych do uzyskania w istniejacych wspótczesnych liniach walcowania $i$ regulowanego chtodzenia po walcowaniu. Wykonano symulacje fizyczne ciagnienia, szeroki zakres ilościowych badań mikrostruktury metodami mikroskopii świetlnej $i$ skaningowej mikroskopii elektronowej oraz pomiary wtaściwości mechanicznych. Próby weryfikacyjne podatności do ciagnienia z dużym odkształceniem sumarycznym wykonano w przemystowej ciagarni drutu.

Stowa kluczowe: walcówka perlityczna, mikrostruktura, właściwości mechaniczne, ciagnienie z dużym odkształceniem

\section{INTRODUCTION}

Wire rod with high ability to drawing allows the use of a large total degree of cross-section reduction without inter-operational heat treatment; therefore the microstructure and properties conditioning the use of large reduction are the basic technological features of material to be drawn. As a result of many years of research in industrial and scientific centres, extensive knowledge on the impact of the type

Corresponding Authors: dariusz.wozniak@imz.pl bogdan.garbarz@imz.pl and morphological features of pearlitic wire rod microstructure on ability to drawing was collected and presented in publications. It was found, among others, that the reduction of the average interlamellar spacing in pearlite improves the plasticity of steel, measured by reduction of area and elongation in a tensile test, and at the same time increases yield strength and tensile strength, which in turn increases drawability. Hard phases in the form of martensite and/or bainite grains, which can form mainly as a result of element segregation, as well as proeutectoid ferrite precipitates, adversely affect the wire rod's susceptibility to drawing. Despite extensive literature, no test results establishing a direct 
quantitative correlation between microstructure parameters and mechanical properties of a pearlitic wire rod or pearlitic-ferritic wire rod and the results of the drawing process determining drawability are yet available.

The purpose of the study, the results of which are contained in this article, was to deepen knowledge of the quantitative relationships between mechanical properties and microstructural parameters of pearlitic wire rod and susceptibility to drawing with large cross section reduction above $90 \%$. To achieve this goal, physical drawing simulations, a wide range of quantitative microstructure investigation using light microscopy and scanning electron microscopy, and measurement of mechanical properties using a quasistatic tensile test were performed. The tests were carried out on sections of $0.7 \% \mathrm{C}-0.60 / 0.70 \% \mathrm{Mn}(\mathrm{C} 70 \mathrm{D} 2 / \mathrm{C} 72 \mathrm{D} 2)$ pearlitic carbon-manganese steel wire rod with a diameter of $5.5 \mathrm{~mm}$, from batches supplied by five manufacturers. Drawability verification trials with large reduction were performed in an industrial wire drawing plant.

\section{FACTORS AFFECTING THE DRAWABILITY OF WIRE ROD WITH PEARLITIC STRUCTURE AND PEARLITIC STRUCTURE WITH A SMALL CONTENT OF PROEUTECTOID FERRITE}

Changes in the microstructure of the drawn material cause a progressive change in the value of yield strength, strength and plastic properties during drawing. In order to prevent losing homogeneity of the drawn material, the value of tensile stress in the entire drawing process cannot exceed the strength. Breaking may also occur at tensile stresses lower than the material strength in the case of material defects and/or microstructural heterogeneities. Below are the most important reasons affecting the drawability of carbon-manganese steel wire rod with a pearlitic microstructure (or with a significant content of pearlite in the microstructure). Only one of the potential factors can be decisive or they can interact in aggregation, with differentiated participation of individual factors.

\subsection{CHEMICAL COMPOSITION OF STEEL}

The chemical composition of steel directly or indirectly affects the wire rod drawability. The impact of carbon content is indirect, by affecting the resulting microstructure. Manganese affects the microstructure mainly indirectly, but it also has a direct impact, forming manganese sulphides. Impurity elements such as $\mathrm{S}, \mathrm{P}, \mathrm{Si}$ and $\mathrm{O}$ and any micro-additives of $\mathrm{Al}$ and $\mathrm{Ti}$ affect the properties of wire rods forming non-metallic inclusions and precipitates. Nitrogen can directly affect the properties of the drawn material, resulting in a dynamic ageing effect that reduces plasticity. Dynamic ageing consists in the diffusion of nitrogen atoms into dislocations arising during deformation. Anchoring a part of the mobile dislocations with nitrogen atoms reduces plastic deformability. The effect of the negative influence of nitrogen may be significant at its higher content exceeding 70-80 ppm [1].

\subsection{MICROSTRUCTURE OF THE WIRE ROD}

The type and morphological parameters of wire rod microstructure are among the most important factors determining the possibility of obtaining high drawability. There are no test results available to establish a direct quantita- tive correlation between the parameters of a fully pearlitic or pearlitic-ferritic wire rod structure and the results of the drawing process. However, in many studies it was clearly established that the reduction of the average interlamellar spacing in pearlite results in an improvement in the plasticity of the steel measured by reduction of area and elongation in a tensile test (e.g. [2]). Since the reduction of the interlamellar spacing in pearlite simultaneously increases yield strength and tensile strength, such modification of the microstructure increases drawability. The presence of structural components other than pearlite is another microstructural factor affecting the drawability of high carbon steel. Hard phases in the form of martensite and/or bainite grains, which can form mainly as a result of element segregation, should not occur in wire rods with high drawability. Also, proeutectoid ferrite is not a desirable phase in high-carbon wire rod [3-5]. If ferrite is present in a small amount, its morphology and distribution are important. A particularly unfavourable form of ferrite are the continuous layers along the grain boundaries of prior austenite. A more favourable morphological form are fine ferrite grains evenly distributed in the pearlitic matrix. The presence of ferrite in the subsurface layer as a result of wire rod decarburisation is also disadvantageous. It should be emphasised that the required microstructural parameters of wire rod to be drawn should show the smallest scattering along the circumference of the coils, because even a small fragment of wire rod that does not meet the required parameters determines the break $[6,7]$.

The average interlamellar spacing of pearlite depends on the average pearlitic transformation temperature and - to a lesser extent - on the chemical composition of steel. Alloying elements affect the interlamellar spacing in pearlite mainly by affecting the temperature of the pearlitic transformation, and in the process of continuous cooling - on the location of the pearlitic transformation start and end curves (on the CCT graph). For a particular chemical composition of steel, the average interlamellar spacing in pearlite depends only on the actual average transformation temperature, inversely proportional to the amount of supercooling below the equilibrium eutectoid transformation temperature, according to the following approximate relationship [8-11]:

$$
S_{0}[\mu \mathrm{m}]=\frac{B}{\Delta T\left[{ }^{\circ} \mathrm{C}\right]}
$$

where $S_{0}$ is the average interlamellar spacing measured perpendicular to cementite plates, $B$ is a constant depending on the chemical composition of the steel, and $\Delta T$ is supercooling below the equilibrium temperature of the eutectoid transformation $A_{1}$. For continuously cooled carbon-manganese steels containing $0.70-0.76 \% \mathrm{C}$ and $0.60-1.2 \% \mathrm{Mn}$, for a supercooling value $\Delta T$ from the range of $50-150^{\circ} \mathrm{C}$ (with $A_{1} \approx 725^{\circ} \mathrm{C}[8]$ ), the constant $B$ is approx. $15 \mu \mathrm{m} \cdot{ }^{\circ} \mathrm{C}[10,12$, 13]. When determining the cooling parameters for wire rods, the effect of recalescence, i.e. heat generated during strongly exothermic pearlitic transformation, should be taken into account, which should be additionally removed in the process of wire rod cooling [14].

The type of the obtained pearlitic microstructure and the amount of undesirable free ferrite is also affected by the size of austenite grain immediately before pearlitic transformation. Too fine austenite grain increases the amount of precipitated proeutectoid ferrite and increases the temperature of pearlitic transformation and, consequently, increases interlamellar spacing in pearlite [15]. 


\subsection{NON-METALLIC INCLUSIONS, INTERNAL DISCONTINUITIES AND SEGREGATION OF ELEMENTS}

Non-metallic inclusions and internal discontinuities (microcracks, voids, tears) as nuclei of cracks can be an important cause of deterioration of the wire rod's susceptibility to drawing and, as a consequence, lead to breakages. Non-deformable particles, such as $\mathrm{Al}_{2} \mathrm{O}_{3}$, in particular those of large sizes and occurring in clusters, are the inclusions that particularly affect susceptibility to drawing [16]. Segregation of elements affects the non-uniformity of the final wire rod microstructure and the possibility of the formation of undesirable structural components (excessive amounts of ferrite in depleted areas and the formation of bainite and/or martensite in areas enriched with carbon and manganese). Inhomogeneities in the distribution of elements in the wire rod volume arise as a result of inheritance of interdendritic segregation and central segregation resulting from solidification of steel during continuous casting. If specific casting parameters are not used to minimise micro- and macro-segregation of elements (low liquid steel overheating, effective electromagnetic stirring, and distribution of spray cooling intensity adjusted to the steel grade and ingot cross-section), this clearly affects the possibility of obtaining homogeneous wire rod properties, both on the cross section and along the length [17].

\subsection{MORPHOLOGY AND PHASE COMPOSITION OF OXIDES ON THE SURFACE OF THE WIRE ROD}

Depending on the surface temperature of the wire rod during loop laying and forming the coil, and - to a lesser extent - depending on the chemical composition of the wire rod, various types of iron oxides are formed in the scale layer, with different thickness, morphology and adhesion to the steel substrate. The temperature of the wire rod directly behind the head laying the loops and the method and intensity of cooling on the conveyor affect the formation of individual types of iron oxides: wüstite $(\mathrm{FeO})$, magnetite $\left(\mathrm{Fe}_{3} \mathrm{O}_{4}\right)$ and hematite $\left(\mathrm{Fe}_{2} \mathrm{O}_{3}\right)$. The last two of these compounds, often formed as a layer between the steel surface and wüstite, are unfavourable due to the reduced susceptibility to removal, both with mechanical and chemical methods [18].

The surface quality of the cleaned wire rod depends on the properties of the surface oxide layer and the method used to remove them. If the oxide layer is not completely removed, the coefficient of friction between the surface of the wire rod and the surface of the drawing cone increases in the drawing process, which increases the drawing force and can lead to wire breakage.

\section{METHODOLOGY}

The subject of the study were sections of C70D2 and C72D2 non-alloy steel wire rod with a diameter of $5.5 \mathrm{~mm}$. The scope of studies, tests and measurement included:

- control chemical analysis of the investigated wire rods,

- measurement of mechanical properties of the wire rod in a static tensile test (determination of $R_{\mathrm{p} 0.2}, R_{\mathrm{m}}, A_{5}, A_{\mathrm{gt}}, Z$ ),

- microstructure investigation including observation and quantitative analysis of phase components (content of proeutectoid ferrite and resolvable pearlite - i.e. pearlite with a large interlamellar spacing, distinguishable by means of a light microscope at 500 $\times$ magnification, and measurement of interlamellar spacing in pearlite),

- simulation drawing tests and drawing tests in industrial conditions.

The measurement of mechanical properties in a tensile test was carried out on samples being sections of a 250$300 \mathrm{~mm}$ long wire rod, in accordance with the PN-EN ISO 6892-1:2010 standard. The methodology of simulation drawing tests and the conditions of industrial tests are given in the relevant sub-sections containing the description and results of these tests. The wire rod microstructure examination was carried out on cross-sections in the central area, in the middle of the length of the radius and - in selected cases - in the subsurface area at a distance of 100-300 $\mu \mathrm{m}$ from the surface. The interlamellar spacing in pearlite (parameter $S_{0}$ in Fig. 1a) was determined on the basis of the number of intersections of cementite lamellae with the secant a)

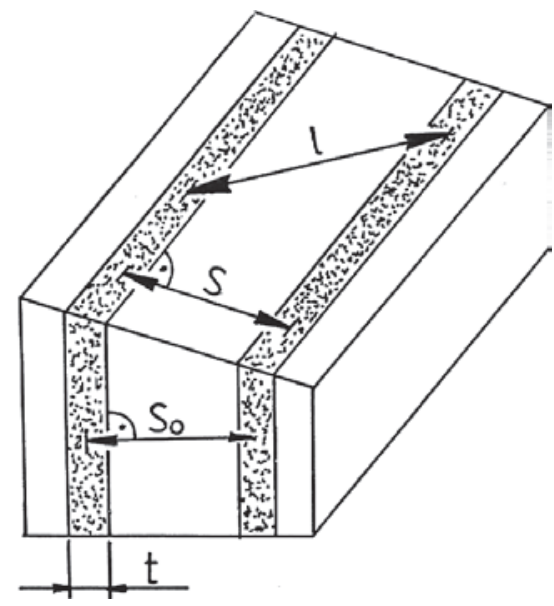

b)

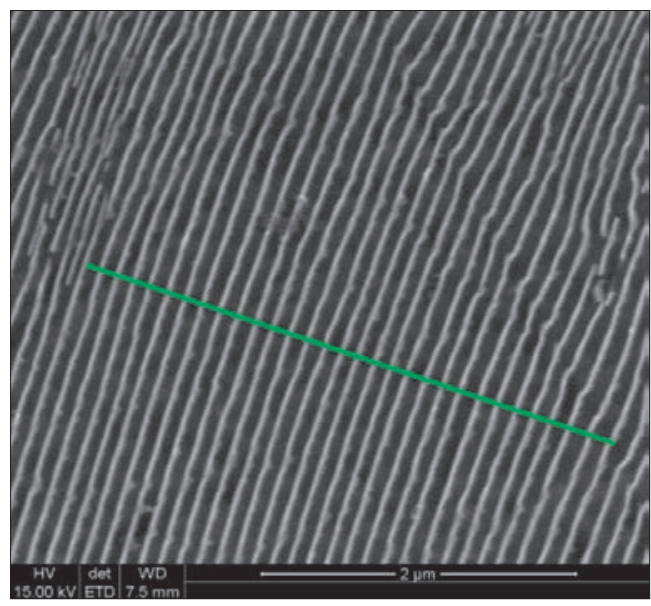

Fig. 1. a) Parameters describing interlamellar spacing in pearlite: $l$ - spacing determined using the linear intercept method on a random planar section, $S$ - interlamellar spacing determined using the intercept method using lines perpendicular to cementite lamellae on random planar section, $S_{0}$ - true perpendicular interlamellar spacing in pearlite, $t$ - thickness of cementite lamellae in pearlite [8,9]; b) illustration of the method applied to measure interlamellar spacing $S_{0}$ on an SEM micrograph

Rys. 1. a) Parametry opisujące odległość płytek w perlicie: $l$ - cięciwa określona metodą siecznych przypadkowych na losowej płaszczyźnie przekroju, $S$ - prostopadła odległość międzypłytkowa określona na losowej płaszczyźnie przekroju, $S_{0}$ - rzeczywista prostopadła odległość międzypłytkowa w perlicie, $t$ - grubość płytek cementytu w perlicie $[8,9]$; b) ilustracja zastosowanej metody pomiaru odległości międzypłytkowej $S_{0}$ na obrazie SEM 
perpendicular to the arrangement of lamellae on the microsection, and pearlite colony areas characterised by perpendicular or near perpendicular arrangement of cementite lamellae with respect to the plane of the microsection were selected for analysis (Fig. 1b). $S_{0}$ measurement did not include coarse pearlite colonies characterised by a lamellar structure distinguishable by means of a light microscope (LM) at a magnification of $500 \times$ or less. In quantitative metallographic tests, sufficiently large sets of measurement results were used so that the relative error of measurement did not exceed $5 \%$. For each sample area examined, at least 250 secant intersections with cementite lamellae were used to calculate interlamellar spacing. The measurement was taken on microstructure images obtained using scanning electron microscopy (SEM) at 20,000 $\times$ magnification. The volume fraction of proeutectoid ferrite was determined on the cross-section of the samples using the method of quantitative analysis of microstructure images made at an $800 \times$ magnification using the SEM method. In each case, the area of analysis was $0.08 \mathrm{~mm}^{2}$. The volume fraction of resolvable pearlite was determined on the cross-section of the samples in the $1 / 2$ radius area and/or in the central area, using the method of quantitative analysis of microstructure images carried out using light microscopy (OM) at 500× magnification, on an area of $0.24 \mathrm{~mm}^{2}$. In English standards (EN ISO 16120-4:2011) the name "resolvable pearlite" is defined as a "two-phased structure in which ferrite and iron carbide lamellae can be clearly observed under optical microscopy", i.e. a two-phase structure in which ferrite and carbide lamellae can be distinguished using a light microscope.

\section{MAIN MICROSTRUCTURAL CAUSES OF INSUFFICIENT SUSCEPTIBILITY TO DRAWING OF PEARLITIC WIRE ROD WITH PROEUTECTOID FERRITE - CASE STUDY}

In order to illustrate the microstructural causes of insufficient susceptibility to drawing of pearlitic wire rod with proeutectoid ferrite, which are generally described in Section 2 , the results of tests of the wire rod batch that broke during drawing are presented. The tests were carried out on $5.5 \mathrm{~mm}$ diameter wire rod sections made of C70D2 steel containing $0.70 \% \mathrm{C}$ and $0.64 \% \mathrm{Mn}$ (NP designation) and on samples of $2.2 \mathrm{~mm}$ diameter wire from this wire rod, which broke during drawing. The mechanical properties of the wire rod determined in the tensile test were as follows: $R_{\mathrm{p} 0.2}=609 \mathrm{MPa}, R_{\mathrm{m}}=910 \mathrm{MPa}, A=14.3 \%, A_{\mathrm{gt}}=6.4 \%$, $Z=33 \%$. Table 1 shows the results of assessing the parameters of the NP wire rod microstructure, and Fig. 2 shows examples of microstructure images.

Based on the observations of the fractures and microstructure of the wires that broke during the drawing process, it was determined that the cracks are of the V-type axial rupture nature, Fig. 3. The cracks nucleation sites were the proeutectoid ferrite areas surrounding the pearlite colonies (Fig. 3a), and further propagation took place in the structure of deformed coarse pearlite (Fig. $3 \mathrm{~b}$ ). The analysis showed that the direct causes of wire breakage during drawing were inadequate microstructure: too large interlamellar spacing in pearlite (significant content of coarse pearlite) and unfavourable morphology and distribution of proeutectoid ferrite.

Table 1. Parameters characterising the microstructure of the C70D2 steel wire rod NP Tabela 1. Parametry charakteryzujące mikrostrukturę walcówki NP ze stali C70D2

\begin{tabular}{|c|c|c|c|}
\hline Sample identification & $\begin{array}{c}\text { Average interlamellar spacing } \\
\mathbf{S}_{\mathbf{0}}, \\
{[\mu \mathrm{m}]}\end{array}$ & $\begin{array}{c}\text { Average content of coarse } \\
\text { pearlite } \overline{V_{\mathbf{p}}}, \\
{[\%]}\end{array}$ & $\begin{array}{c}\text { Average content of proeutectoid } \\
\text { ferrite } \\
{[\%]}\end{array}$ \\
\hline NP1 & 0.27 & 42 & 4.1 \\
\hline NP2 & 0.32 & 49 & 4.5 \\
\hline
\end{tabular}
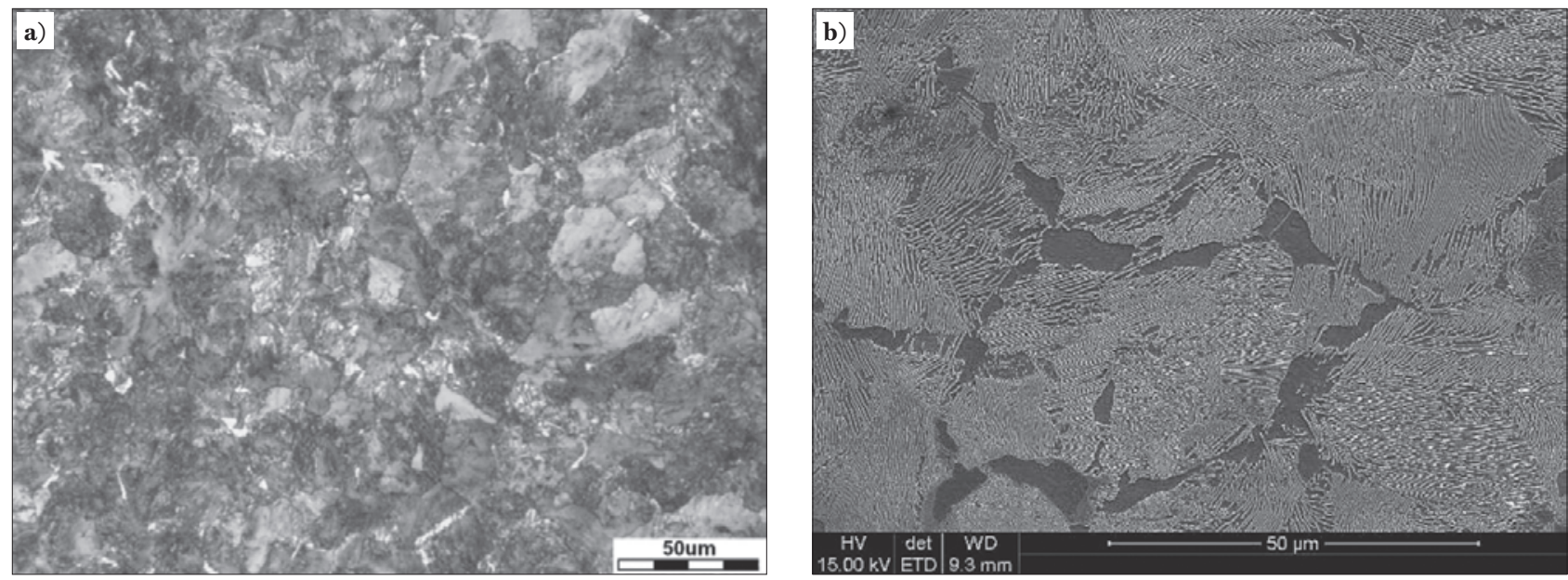

Fig. 2. Examples of images of microstructure of C70D2 steel wire rod NP in the central area, a) perpendicular cross section - LM, b) longitudinal cross section - SEM

Rys. 2. Przykładowe obrazy mikrostruktury walcówki NP ze stali C70D2 w obszarze środkowym przekroju, a) zgład poprzeczny - MS, b) zgład wzdłużny - SEM 

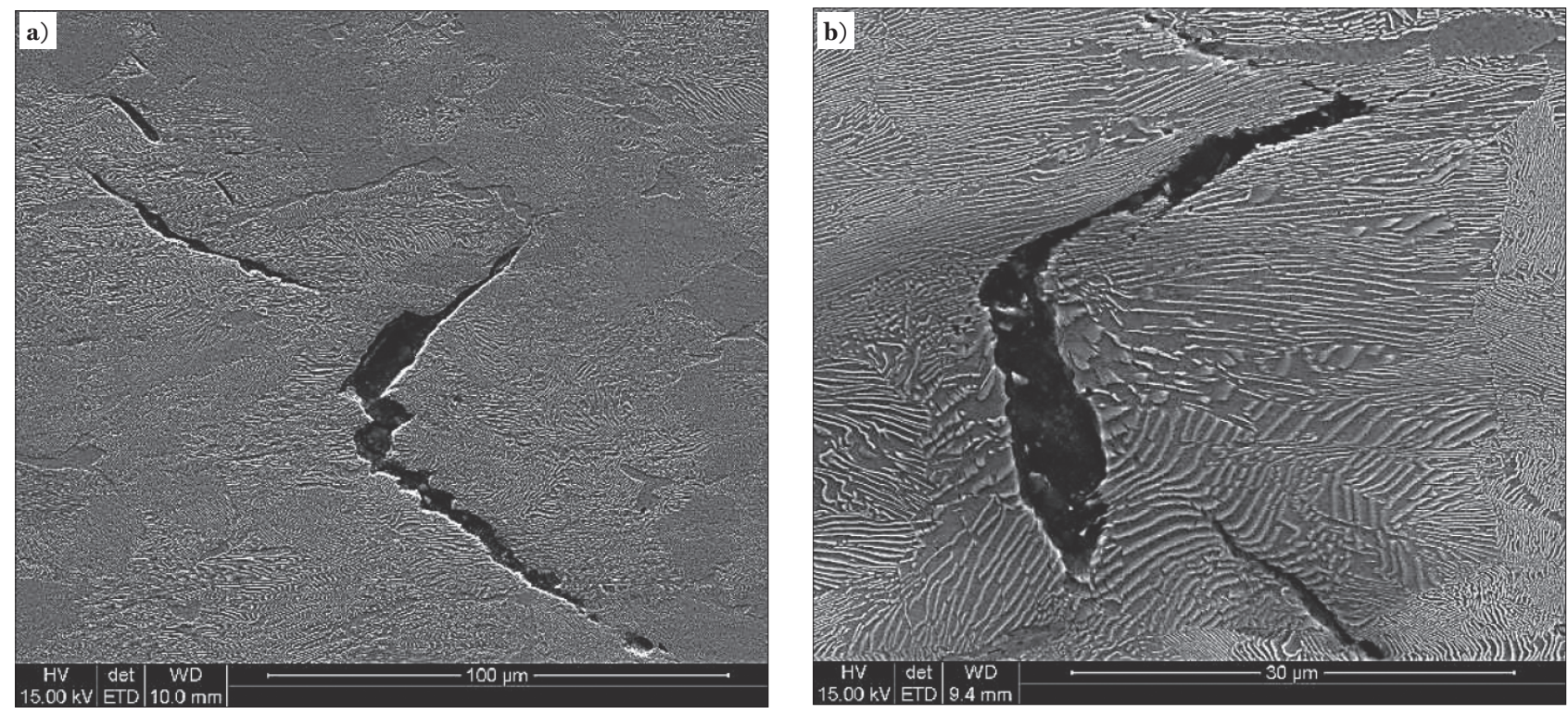

Fig. 3. Microstructure in the central area of a $4.8 \mathrm{~mm}$ diameter wire after drawing of C7OD2 steel wire rod NP, longitudinal cross section, SEM; a) nucleation sites of cracks in areas of proeutectoid ferrite, $b$ ) propagation of cracks through colonies of coarse pearlite

Rys. 3. Mikrostruktura w środku przekroju drutu o średnicy $4,8 \mathrm{~mm}$ po ciągnieniu walcówki NP ze stali C70D2, zgład wzdłużny, SEM; a) miejsca zarodkowania pęknięć w obszarach ferrytu przedeutektoidalnego, b) propagacja pęknięć w koloniach perlitu grubopłytkowego

\section{SELECTION OF WIRE RODS FOR DRAWING WITH LARGE REDUCTION AND CHARACTERISTICS OF THEIR MECHANICAL PROPERTIES AND MICROSTRUCTURE}

The requirements for the chemical composition of steel, mechanical properties and microstructure of a $5.5 \mathrm{~mm}$ diameter wire rod are contained in the PN-EN ISO 16120 and PN-EN 10016 standards [19, 20]. In the case of C70D and $\mathrm{C} 72 \mathrm{D}$ steel wire rod intended for special applications, the PN-EN 10016-4 and PN-EN ISO 16120-4 standards specify a maximum nitrogen content of $70 \mathrm{ppm}$ and sums of $\mathrm{Cu}, \mathrm{Ni}$ and $\mathrm{Cr}$ content below $0.30 \%$. These standards do not specify the criteria for the tensile strength and reduction of area values. The requirements for microstructural parameters of $\mathrm{C} 70 \mathrm{D}$ and $\mathrm{C} 72 \mathrm{D}$ steel wire rods intended for drawing are contained in the PN-EN ISO 16120-4 standard in Annex $\mathrm{D}$ [19] and they specify that the wire rod should have a microstructure of homogeneous pearlite without areas of martensite and bainite, with volume fraction of coarse pearlite not exceeding $25 \%$. Meeting the requirements contained in the standards is insufficient to ensure high drawability with very large cross section reduction.

The earlier work of the authors of this article and the analysis of the literature on the properties of pearlitic wire rods indicate that in order to ensure high drawability with large reduction, the microstructure of the wire rod should be a homogeneous fine pearlite with the smallest possible interlamellar spacing $S_{0}$ below values in the range of 0.16-0.20 $\mu \mathrm{m}$. Considering the initial requirements for pearlite homogeneity and interlamellar spacing values, on the basis of comparative tests of microstructure and mechanical properties, batches of C72D2 steel wire rods from five manufacturers were selected (Table 2) and then their drawability was assessed.

The results of measurement of mechanical properties of the analysed wire rod batches are shown in Table 3 . The values of tensile strength $\left(R_{\mathrm{m}}\right)$ and reduction of area $(Z)$ were adopted as the main indices preliminarily determining the susceptibility of wire rod to drawing. The values of these indices for the batch of wire rod selected for the assessment of susceptibility to drawing with a large reduction in area are in the ranges $R_{\mathrm{m}}$ : $1035-1123 \mathrm{MPa}$ and $\mathrm{Z}: 42-57 \%$.

Table 4 contains the results of the quantitative analysis of interlamellar spacing in the pearlite structure of the tested wire rod batches. For selected cases, measurement was taken in the subsurface layer and in the central area of the wire rod. The results of the measurement of volume fraction of coarse pearlite and proeutectoid ferrite are shown in Table 5. Fig. 4 contains examples of diagrams illustrating the statistical distribution of interlamellar spacing $S_{0}$ in pearlite determined on samples from the $\mathrm{A} 1$ wire rod batch, and the microphotographs in Fig. 5 show the typical microstructure of the examined wire rod batches.

Table 2. Specification of $5.5 \mathrm{~mm}$ diameter C72D2 steel wire rod batches designed for microstructural and mechanical investigation Tabela 2. Zestawienie partii walcówek o średnicy 5,5 mm ze stali C72D2 przeznaczonych do badań mikrostrukturalnych i wytrzymałościowych

\begin{tabular}{|l|c|c|c|c|c|}
\hline \multirow{2}{*}{$\begin{array}{l}\text { Designation of the wire rod } \\
\text { manufacturer }\end{array}$} & \multicolumn{2}{|c|}{ A } & \multirow{2}{*}{ C } & \multirow{2}{*}{ E } \\
\cline { 2 - 6 } & Batch A1 & Batch A2 & & \multirow{2}{*}{ D } \\
\hline C content [\%] & 0.70 & 0.74 & 0.73 & 0.71 & 0.71 \\
\hline Mn content [\%] & 0.62 & 0.63 & 0.67 & 0.65 & 0.60 \\
\hline
\end{tabular}


Table 3. Mechanical properties of investigated batches of $5.5 \mathrm{~mm}$ diameter C72D2 steel wire rod Tabela 3. Właściwości mechaniczne badanych partii walcówki o średnicy 5,5 mm ze stali C72D2

\begin{tabular}{|c|c|c|c|c|c|c|c|}
\hline $\begin{array}{c}\text { Manufacturer } \\
\text { designation }\end{array}$ & Batch & Coil designation & $\begin{array}{c}\boldsymbol{R}_{\mathrm{p0.2}} \\
{[\mathrm{MPa}]}\end{array}$ & $\begin{array}{c}\boldsymbol{R}_{\mathrm{m}} \\
{[\mathrm{MPa}]}\end{array}$ & $\begin{array}{c}A \\
{[\%]}\end{array}$ & $\begin{array}{c}A_{\mathrm{gt}} \\
{[\%]}\end{array}$ & $\begin{array}{c}Z \\
{[\%]}\end{array}$ \\
\hline \multirow{6}{*}{ A } & \multirow{2}{*}{ A1 } & 14 & 618 & 1035 & 18.4 & 8.23 & 51 \\
\hline & & 19 & 595 & 1042 & 18.8 & 11.14 & 47 \\
\hline & \multirow{4}{*}{ A2 } & $2 \mathrm{~K}$ & 643 & 1075 & 17.3 & 7.73 & 49 \\
\hline & & $6 \mathrm{~K}$ & 680 & 1097 & 17.4 & 7.91 & 51 \\
\hline & & $7 \mathrm{~K}$ & 615 & 1068 & 16.8 & 7.79 & 50 \\
\hline & & $8 \mathrm{~K}$ & 649 & 1089 & 16.2 & 7.57 & 47 \\
\hline \multirow{2}{*}{ B } & B1 & - & 694 & 1123 & 16.7 & 7.48 & 52 \\
\hline & $\mathrm{B} 2$ & - & 673 & 1086 & 16.3 & 6.32 & 50 \\
\hline \multirow{2}{*}{$\mathrm{C}$} & $\mathrm{C} 1$ & - & 685 & 1081 & 16.7 & 7.11 & 57 \\
\hline & $\mathrm{C} 2$ & - & 705 & 1123 & 17.0 & 6.71 & 57 \\
\hline \multirow{2}{*}{$\mathrm{D}$} & D1 & - & 610 & 1035 & 13.7 & 7.00 & 42 \\
\hline & D2 & - & 633 & 1050 & 15.3 & 8.05 & 44 \\
\hline \multirow{2}{*}{$\mathrm{E}$} & E1 & - & 653 & 1078 & 16.0 & 6.58 & 47 \\
\hline & E2 & - & 609 & 1066 & 16.7 & 8.51 & 46 \\
\hline
\end{tabular}

Table 4. Results of quantitative analysis of interlamellar spacing in the investigated batches of $5.5 \mathrm{~mm}$ diameter C72D2 steel wire rod Tabela 4. Wyniki analizy ilościowej odległości międzypłytkowej perlitu w mikrostrukturze badanych partii walcówki o średnicy 5,5 mm ze stali C72D2

\begin{tabular}{|c|c|c|c|c|c|c|}
\hline $\begin{array}{c}\text { Manufacturer } \\
\text { designation }\end{array}$ & Batch & $\begin{array}{c}\text { Coil } \\
\text { designation }\end{array}$ & $\begin{array}{l}\text { Area along the } \\
\text { loop's length }\end{array}$ & $\begin{array}{l}\text { Analysis area on the wire } \\
\text { rod's cross section }\end{array}$ & $\begin{array}{c}\text { Average interlamellar } \\
\text { spacing, } S_{0},[\mu \mathrm{m}]\end{array}$ & $\begin{array}{c}\text { Standard deviation, } s \\
{[\mu \mathrm{m}]}\end{array}$ \\
\hline \multirow{12}{*}{ A } & \multirow{8}{*}{$\mathrm{A} 1$} & \multirow{4}{*}{14} & \multirow{2}{*}{1} & surface & 0.114 & 0.022 \\
\hline & & & & centre & 0.148 & 0.025 \\
\hline & & & \multirow{2}{*}{2} & surface & 0.121 & 0.027 \\
\hline & & & & centre & 0.149 & 0.033 \\
\hline & & \multirow{4}{*}{19} & \multirow{2}{*}{1} & surface & 0.109 & 0.026 \\
\hline & & & & centre & 0.149 & 0.019 \\
\hline & & & \multirow{2}{*}{2} & surface & 0.111 & 0.021 \\
\hline & & & & centre & 0.162 & 0.035 \\
\hline & \multirow{4}{*}{ A2 } & 7 & - & centre & 0.144 & 0.037 \\
\hline & & 8 & - & centre & 0.132 & 0.038 \\
\hline & & $7 \mathrm{~K}$ & - & centre & 0.123 & 0.029 \\
\hline & & $8 \mathrm{~K}$ & - & centre & 0.136 & 0.037 \\
\hline \multirow{2}{*}{ B } & \multirow{2}{*}{-} & \multirow{2}{*}{-} & \multirow{2}{*}{-} & surface & 0.113 & 0.021 \\
\hline & & & & centre & 0.153 & 0.028 \\
\hline \multirow{2}{*}{$\mathrm{C}$} & \multirow{2}{*}{-} & \multirow{2}{*}{-} & \multirow{2}{*}{-} & surface & 0.132 & 0.021 \\
\hline & & & & centre & 0.121 & 0.025 \\
\hline \multirow{2}{*}{$\mathrm{D}$} & \multirow{2}{*}{-} & \multirow{2}{*}{-} & \multirow{2}{*}{-} & surface & 0.137 & 0.026 \\
\hline & & & & centre & 0.156 & 0.035 \\
\hline \multirow{2}{*}{$\mathrm{E}$} & \multirow{2}{*}{-} & \multirow{2}{*}{-} & \multirow{2}{*}{-} & surface & 0.111 & 0.020 \\
\hline & & & & centre & 0.153 & 0.039 \\
\hline
\end{tabular}

Table 5. Results of quantitative analysis of volume fraction of coarse lamellae pearlite and proeutectoid ferrite in the microstructure of a $5.5 \mathrm{~mm}$ diameter C72D2 steel wire rod ( $\mathrm{nm}$ - not measured, ow - assessment by comparison with standard patterns)

Tabela 5. Wyniki analizy ilościowej udziału objętościowego perlitu grubopłytkowego i ferrytu przedeutektoidalnego w mikrostrukturze badanych partii walcówki o średnicy $5,5 \mathrm{~mm}$ ze stali C72D2 (nm - nie mierzono, ow - ocena metodą porównania z wzorcami)

\begin{tabular}{|c|c|c|c|c|}
\hline $\begin{array}{l}\text { Manufacturer } \\
\text { designation }\end{array}$ & Batch & Coil designation & $\begin{array}{l}\text { Average volume fraction of coarse } \\
\text { pearlite } \overline{V_{\mathrm{p}}},[\%]\end{array}$ & $\begin{array}{c}\text { Average volume fraction of proeutectoid } \\
\text { ferrite, } \bar{V}_{\alpha}[\%]\end{array}$ \\
\hline \multirow[t]{6}{*}{$\mathrm{A}$} & \multirow[t]{2}{*}{$\mathrm{A} 1$} & 14 & 7.2 & 2.62 \\
\hline & & 19 & 4.8 & 1.36 \\
\hline & \multirow[t]{4}{*}{ A2 } & 7 & 1.9 & 0.70 \\
\hline & & 8 & 5.4 & 0.90 \\
\hline & & $7 \mathrm{~K}$ & 3.4 & 0.30 \\
\hline & & $8 \mathrm{~K}$ & 7.0 & 0.60 \\
\hline $\mathrm{B}$ & - & - & $\mathrm{nm} ;$ ow $<5.0$ & $<1.0$ \\
\hline $\mathrm{C}$ & - & - & $\mathrm{nm} ;$ ow $<5.0$ & 1.14 \\
\hline $\mathrm{D}$ & - & - & $\mathrm{nm} ;$ ow $<5.0$ & $<1.0$ \\
\hline $\mathrm{E}$ & - & - & $\mathrm{nm} ;$ ow $<5.0$ & 1.56 \\
\hline
\end{tabular}



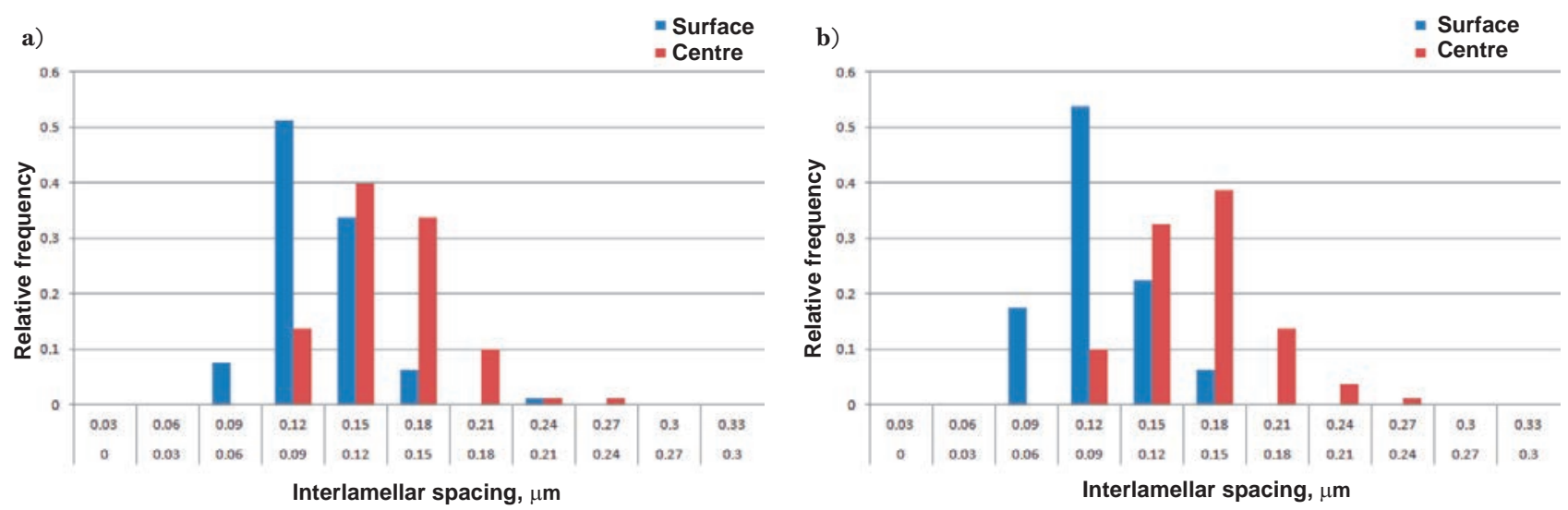

Fig. 4. Examples of diagrams showing statistical distributions of interlamellar spacing $S_{0}$ in pearlite determined for wire rod batch A1: a) coil No. 14, b) coil No. 19

Rys. 4. Przykładowe diagramy obrazujące rozkłady statystyczne odległości międzypłytkowej $S_{0}$ w perlicie, wyznaczone dla partii walcówki A1: a) krąg nr 14, b) krąg nr 19
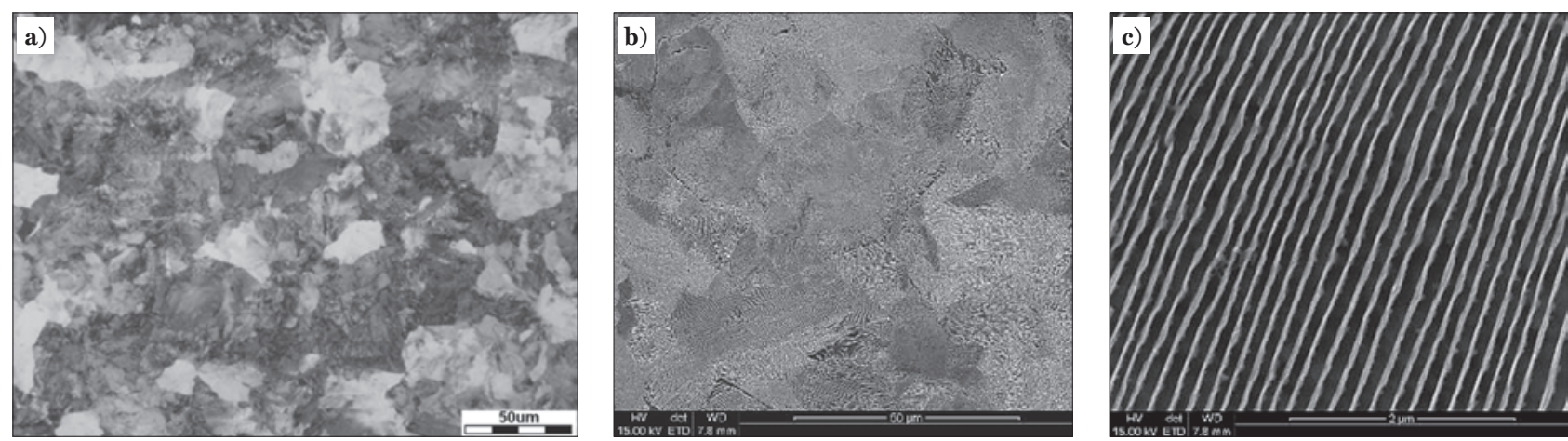

Fig. 5. Microstructure of a specimen from the A2 batch - coil No. $8 \mathrm{~K}$ at a depth of $1 / 2$ of the wire rod radius: a) LM, b) SEM, c) SEM Rys. 5. Mikrostruktura próbki z partii A2 - krąg nr 8K, na głębokości 1/2 promienia walcówki: a) MS, b) SEM, c) SEM

\section{PHYSICAL SIMULATION OF SELECTED DRAWING PROCESS PARAMETERS}

Physical simulations of the drawing process, using parameters that can be achieved under conditions of this type of tests, which in the range of drawing rate are significantly lower than the values achieved in industrial conditions, were carried out in order to determine the preliminary characteristics of the susceptibility to drawing of the tested wire rod batches. Wire rod loops from batch A1 - coil 19 - were selected as test material representing the tested batches.

The drawing tests were carried out on a draw bench machine, which is part of the equipment of the LPS line - module F, at the laboratory of the Eukasiewicz Research Network - Institute for Ferrous Metallurgy. The LPS-F drawing machine is characterised by a maximum drawing force of $100 \mathrm{kN}$, maximum drawing rate of $10 \mathrm{~m} / \mathrm{min}$ and a maximum length of drawn wire of $6 \mathrm{~m}$. For drawing tests, sec-

Table 6. Parameters of exemplary industrial technology of $5.5 \mathrm{~mm}$ C72D2 steel wire rod drawing into a $1.70 \mathrm{~mm}$ wire with a total cross section reduction of approx. $91 \%$

Tabela 6. Parametry przykładowej przemysłowej technologii ciąnnienia walcówki o średnicy 5,5 mm ze stali C72D2 na drut o średnicy $1,70 \mathrm{~mm}$, z sumarycznym ubytkiem przekroju ok. $91 \%$

\begin{tabular}{|c|c|c|c|c|}
\hline Draw No. & $\begin{array}{c}\text { Die's inner diameter } \\
{[\mathrm{mm}]}\end{array}$ & $\begin{array}{c}\text { Angle } \\
{\left[{ }^{\circ}\right]}\end{array}$ & $\begin{array}{c}\text { Cross sectional area } \\
{\left[\mathbf{m m}^{2}\right]}\end{array}$ & $\begin{array}{c}\text { Cross section reduction } \\
{[\%]}\end{array}$ \\
\hline 0 & - & 12 & 23.76 & 25.73 \\
\hline 1 & 4.74 & 12 & 17.65 & 25.18 \\
\hline 2 & 4.10 & 12 & 13.20 & 24.61 \\
\hline 3 & 3.56 & 12 & 9.95 & 23.19 \\
\hline 4 & 3.12 & 12 & 7.65 & 21.75 \\
\hline 5 & 2.76 & 12 & 5.98 & 20.56 \\
\hline 6 & 2.46 & 12 & 4.75 & 18.02 \\
\hline 7 & 2.20 & 12 & 3.80 & 16.18 \\
\hline 8 & 1.99 & 9 & 3.11 & 2.60 \\
\hline 9 & 1.82 & 9 & 2.22 & $\mathbf{9 0 . 6 7}$ \\
\hline 10 & 1.68 & 9 & & \\
\hline
\end{tabular}


Table 7. Measured parameters of exemplary test of drawing of wire rod with a nominal diameter of $5.5 \mathrm{~mm}$ into a $1.70 \mathrm{~mm}$ diameter wire in an LPS-F draw bench machine

Tabela 7. Zmierzone parametry przykładowego testu ciągnienia walcówki o średnicy nominalnej 5,5 mm na drut o średnicy 1,70 mm w ciągarce ławowej LPS-F

\begin{tabular}{|c|c|c|c|c|c|c|c|}
\hline \multicolumn{3}{|c|}{ Draw plate } & \multicolumn{3}{|c|}{ Wire } & \multirow{2}{*}{$\begin{array}{c}\text { Maximum } \\
\text { drawing force } \\
{[\mathbf{k N}]}\end{array}$} & \multirow{2}{*}{$\begin{array}{c}\text { Maximum } \\
\text { stress } \\
{[\mathrm{MPa}]}\end{array}$} \\
\hline $\begin{array}{c}\text { Die's inner } \\
\text { diameter } \\
{[\mathrm{mm}]}\end{array}$ & $\begin{array}{c}\text { Cross sectional } \\
\text { inner area of the die } \\
{\left[\mathrm{mm}^{2}\right]}\end{array}$ & $\begin{array}{c}\text { Cross section } \\
\text { reduction } \\
{[\%]}\end{array}$ & $\begin{array}{c}\text { Average } \\
\text { diameter } \\
{[\mathrm{mm}]}\end{array}$ & $\begin{array}{c}\text { Cross sectional } \\
\text { area } \\
{\left[\mathrm{mm}^{2}\right]}\end{array}$ & $\begin{array}{c}\text { Cross section } \\
\text { reduction } \\
{[\%]}\end{array}$ & & \\
\hline- & 23.76 & & & 23.76 & & - & - \\
\hline 4.70 & 17.35 & 26.98 & 4.67 & 17.14 & 27.84 & 7.92 & 462 \\
\hline 4.10 & 13.20 & 23.90 & 4.09 & 13.11 & 23.51 & 5.73 & 437 \\
\hline 3.58 & 10.07 & 23.76 & 3.55 & 9.91 & 24.43 & 8.36 & 844 \\
\hline 3.15 & 7.79 & 22.58 & 3.08 & 7.44 & 24.91 & 7.00 & 941 \\
\hline 2.78 & 6.07 & 22.11 & 2.75 & 5.96 & 19.94 & 5.75 & 965 \\
\hline 2.45 & 4.71 & 22.33 & 2.52 & 4.99 & 16.27 & 5.27 & 1057 \\
\hline $2.29^{1)}$ & 4.12 & 12.63 & 2.27 & 4.06 & 18.57 & 3.25 & 800 \\
\hline 2.22 & 3.87 & 6.02 & 2.20 & 3.82 & 6.06 & 2.26 & 592 \\
\hline 2.00 & 3.14 & 18.84 & 1.92 & 2.88 & 24.43 & 3.19 & 1106 \\
\hline 1.84 & 2.66 & 15.36 & 1.83 & 2.63 & 8.78 & 1.20 & 456 \\
\hline 1.70 & 2.27 & 14.64 & 1.70 & 2.26 & 13.91 & 2.00 & 883 \\
\hline \multicolumn{2}{|c|}{ Total reduction } & 90.45 & \multicolumn{2}{|c|}{ Total reduction } & 90.47 & & \\
\hline
\end{tabular}

${ }^{1)}$ an additional draw was used between draws 6 and 7 - a $\varphi 2.29 \mathrm{~mm}$ mesh in relation to industrial technology

tions of approx. $1.0 \mathrm{~m}$ in length were taken from the loops of wire rod, which were mechanically cleaned to remove scale from the surface. The drawing process was carried out on the basis of the actual technology used for C72D2 steel wire rods, taking into account the limitations in the scope of the possible drawing rates. Table 6 lists the technological parameters used in the process of drawing of a 5.5 diameter $\mathrm{mm}$ wire rod into a $1.70 \mathrm{~mm}$ diameter wire in industrial conditions, and Table 7 shows the measured parameters of one of the drawing tests of a wire rod with a nominal diameter of $5.5 \mathrm{~mm}$ into a $1.70 \mathrm{~mm}$ diameter rod with an LPS-F draw bench.

Based on the results of drawing tests in an LPS-F drawing machine using the actual distribution of draws, which is used in the industrial process of drawing from a diameter of $5.5 \mathrm{~mm}$ to a diameter of $1.70 \mathrm{~mm}$, it was found that the tested wire rod A1 - 19 does not show a tendency to break during the tests. The obtained positive results of simulation tests constituted a preliminary assessment of the susceptibility of wire rod to cold deformation in a state of stress typical for an industrial drawing process with large cross section reduction and were the basis for making a decision to conduct drawing tests in industrial conditions.

\section{DRAWING TESTS IN INDUSTRIAL CONDITIONS}

10 coils of a $5.5 \mathrm{~mm}$ diameter wire rod made of C72D2 steel from batch A2 were selected for supervised drawing tests in industrial conditions (the parameters of the wire rod are given in Tables 2-5). The average weight of the wire rod coil was $2,300 \mathrm{~kg}$. Control measurement of mechanical properties and microstructural parameters were taken on samples cut out randomly from the coil ends, the results of which are given in Table 8 . The obtained values are consistent with the results of detailed tests, which are presented in Tables 3-5.

Before drawing, scale was removed from the wire rod mechanically by bending, followed by cleaning with sandpaper and washing in a drawing line. The drawing tests were carried out using 9 dies with the following internal diameters, (in $\mathrm{mm}$ ):

$$
\begin{aligned}
4.76 \rightarrow 4.10 \rightarrow & 3.56 \rightarrow 3.12 \rightarrow 2.76 \rightarrow 2.47 \rightarrow 2.19 \rightarrow \\
& \rightarrow 1.99 \rightarrow 1.82 \rightarrow 1.68
\end{aligned}
$$

A drawing rate of $16.5 \mathrm{~mm} / \mathrm{s}$, standard for manufacturing a $1.7 \mathrm{~mm}$ diameter wire, was used. The drawing tests were carried out smoothly; in particular no wire breaks occurred. The properties of the wire obtained during the tests met the acceptance requirements in terms of tensile strength and number of twists to break.

Table 8. Mechanical properties and microstructural parameters of $5.5 \mathrm{~mm}$ C72D2 steel wire rod sections from batch A2 designed for industrial drawing tests

Tabela 8. Właściwości mechaniczne i parametry mikrostruktury odcinków walcówki o średnicy 5,5 mm ze stali C72D2 z partii A2, przeznaczonej do przemysłowych prób ciągnienia

\begin{tabular}{|c|c|c|c|c|c|c|c|}
\hline $\begin{array}{c}\text { Steel grade, } \\
\text { wire rod batch }\end{array}$ & $\begin{array}{c}\boldsymbol{R}_{\mathrm{po.2}} \\
{[\mathrm{MPa}]}\end{array}$ & $\begin{array}{c}\boldsymbol{R}_{\mathrm{m}} \\
{[\mathrm{MPa}]}\end{array}$ & $\begin{array}{c}\boldsymbol{A} \\
{[\%]}\end{array}$ & $\begin{array}{c}\boldsymbol{A}_{\mathrm{gt}} \\
{[\%]}\end{array}$ & $\begin{array}{c}\boldsymbol{Z} \\
{[\%]}\end{array}$ & $\begin{array}{c}\text { Average interlamellar } \\
\text { spacing } \boldsymbol{S}_{\mathrm{o}} \\
{[\mu \mathrm{m}]}\end{array}$ & $\begin{array}{c}\text { Average content } \\
\text { of ferrite } \\
{[\%]}\end{array}$ \\
\hline $\begin{array}{c}\mathrm{C} 72 \mathrm{D} 2 \\
\mathrm{~A} 2\end{array}$ & 646 & 1082 & 17.0 & 7.8 & 49 & 0.134 & $\begin{array}{c}\text { Average content } \\
\text { of coarse pearlite } \\
{[\%]}\end{array}$ \\
\hline
\end{tabular}


Wire rod batches from other manufacturers, the mechanical properties and microstructural parameters of which are given in Section 5, showed very good susceptibility to drawing a wire with a diameter of $1.7 \mathrm{~mm}$ in standard industrial conditions.

\section{SUMMARY AND CONCLUSIONS}

In order to develop quantitative cause-and-effect relationships between the mechanical properties and microstructural parameters of pearlitic wire rod and its drawability with a large cross section reduction of over $90 \%$, a wide range of microstructure investigation and measurement of mechanical properties were carried out on sections of C72D2 pearlitic carbon-manganese steel wire rod with a $5.5 \mathrm{~mm}$ diameter from five manufacturers. Next, physical drawing simulations were carried out in a draw bench machine and - finally verification drawing tests with large cross section reduction were performed in the industrial wire drawing line. Based on the existing knowledge, it was assumed that the most important parameters characterising the microstructure and mechanical properties of the wire rod with a large total deformation are: average interlamellar spacing in pearlite, content of coarse pearlite, content of proeutectoid ferrite, tensile strength and reduction of area in the tensile test.

Based on the obtained results, critical levels of parameters characterising the microstructure and mechanical properties of C72D2 steel rods were determined, whose simultaneous fulfilment and their uniformity along the length determine high susceptibility to drawing without inter-operational heat treatment, with a total deformation measured by a cross section reduction of $90 \%$, assuming high quality of the wire rod in relation to metallurgical purity and chemical homogeneity:

- average value of interlamellar spacing in pearlite $\left(S_{0}\right)$ for the entire wire cross section smaller than $0.16 \mu \mathrm{m}$, optimally $0.10-0.13 \mu \mathrm{m}$,

- coarse pearlite content below 10\% (desired achievable value $<5 \%$ ),

- less than $3 \%$ proeutectoid ferrite (desired achievable value $<1.5 \%$ ),

- tensile strength $R_{\mathrm{m}}$ above approx. $1050 \mathrm{MPa}$ (desired achievable value $>1075 \mathrm{MPa}$ ),

- reduction of area $Z$ above $45 \%$ (desired achievable value $>50 \%$ ).

\section{REFERENCES}

[1] E. Brandaleze. Structural Evolution of Pearlite in Steels with Different Carbon Content under Drastic Deformation during Cold Drawing. Procedia Materials Science, 2015 (8), p. 1023-1030.

[2] J.M. Hyzak, I.M. Bernstein. The Role of Microstructure on the Strength and Toughness of Fully Pearlitic Steels. Met. Trans. A, 1976, 7 (8), p. 1217-1224.

[3] K. Nordell, L. Pohjala, M. Rastas. Improvement in drawability of high carbon wire rod. J. Mater. Process. Technol. 1994, 45, p. 557561 .

[4] H. Rastegari, A. Kermanpur, A. Najafizadeh. Investigating the effects of short time austenitizing and cooling rate on pearlitic microstructure and mechanical properties of a hot rolled plain eutectoid carbon steel. Materials and Design, 2015, 67, p. 217-223

[5] W.Y. Choo, C.M. Bae. Drawing Behavior of Pearlitic Steel Wire Rods Controlled by Boron Addition in Medium Carbon Steel. ISIJ International, 2002, 42 (Supplement), p. S47-S51.

[6] S. Cao. Production practice of C82DA high carbon steel wire rod for conversion to wire. In: 3rd Int. Conf. IC3ME. China, Guangzhou, 27-28 June 2015, p. 147-150.

[7] S. Cao. Development of 72A high carbon wire rod for bead wire. In: Int. Conf. ICACIE. India, Odisha, 21-23 December 2016, p. 123126.

[8] N. Ridley. A Review of the Data on the Interlamellar Spacing of Pearlite. Met. Trans. A, 1984, 15 (6), p. 1019-1036.

[9] B. Garbarz. Stale mikrostopowe przeznaczone na wyroby kute. Prace IMŻ, 1991, 43 (3-4), p. 23-41.

[10] A.R. Marder, B.L. Bramfitt. The Effect of Morphology on the Strenght of Pearlite. Metall. Trans. A, 1976, 7 (3), p. 365-372.

[11] P.C. Campbell, E.B. Hawbolt, J.K. Brimacombe. Microstructural Engineering Applied to the Controlled Cooling of Steel Wire Rod Part II Microstructural Evolution and Mechanical Properties Correlations. Metall. Trans. A, 1991, 22 (11), p. 2779-2790.
[12] F.B. Pickering, B. Garbarz. The effect of transformation temperature and prior austenite grain size on the pearlite colony size in vanadium treated pearlitic steels. Scripta Metall., 1987, 21 (3), p. 249-253.

[13] F.B. Pickering, B. Garbarz. Strengthening in pearlite formed from thermomechanically processed austenite in vanadium steel, and implications for toughness. Mater. Sci. Technol., 1989, 5 (3), p. 227-237.

[14] I. Jain, S. Lenka, S.K. Ajmani, S. Kundu. An Approach to Heat Transfer Analysis of Wire Loops Over the Stelmor Conveyor to Predict the Microstructural and Mechanical Attributes of Steel Rods. J. of Thermal Science and Engineering Appl., 2016, 8 (2), p. 1-11.

[15] H. Yada, M. Murakami, M. Ochiai, T. Mori, J. Tominaga. Controlled cooling of wire rods. Nippon Steel Tech. Rep., 1983, 21, p. 203-215.

[16] M. Yilmaz. Failures during the production and usage of steel wires. Journal of Materials Processing Technology, 2006, 171 (2), p. 232239.

[17] Y. Ji, H. Tang, P. Lan, Ch. Shang, J. Zhang. Effect of dendritic morphology and central segregation of billet castings on the microstructure and mechanical property of hot-rolled wire rods. Steel Research Int., 2017, 88 (8), p. 1-14.

[18] R. Bhattacharya, G. Jha, S. Kundu, R. Shankar, N. Gope. Influence of cooling rate on the structure and formation of oxide scale in low carbon steel wire rods during hot rolling. Surface \& Coatings Technology, 2006, 201 (3), p. 526-532.

[19] Polski Komitet Normalizacyjny. PN-EN ISO 16120-1:2017-07. Walcówka ze stali niestopowej przeznaczona do produkcji drutuCzęść 1: Wymagania ogólne. Warszawa: PKN, 2018.

[20] Polski Komitet Normalizacyjny. PN-EN ISO 16120-2:2017-04 Walcówka ze stali niestopowej przeznaczona do produkcji drutu - Część 2: Wymagania dla walcówki ogólnego przeznaczenia. Warszawa: PKN, 2017. 